\title{
Seed Bacterization a Novel Prime Tool for Growth Promotion in Tomato (Solanum lycopersicum M.) under in vitro
}

\author{
P. Murali Sankar ${ }^{*}$, T. Raguchander ${ }^{2}$ and S. Shanmugabackiam ${ }^{3}$ \\ ${ }^{1}$ Post-Harvest Laboratory, Department of Plant Pathology, TNAU, Coimbatore-641003, India \\ ${ }^{2}$ Plant Pathology, Agricultural College and Research Institute, Vazhavachanur, \\ Tiruvannamalai-606753, India \\ ${ }^{3}$ Department of Plant Pathology, TNAU, Coimbatore-641003, India \\ *Corresponding author
}

\begin{tabular}{|c|c|}
\hline & A B S T R A C T \\
\hline Keywords & Beneficial microbes group of rhizobacteria such as Pseudomonas spp. and \\
\hline $\begin{array}{l}\text { Rhizobacteria, Seed } \\
\text { bacterization, Growth } \\
\text { promotion, beneficial } \\
\text { microbes, Root } \\
\text { colonization. }\end{array}$ & $\begin{array}{l}\text { Bactllus sp. can serve as, PGPR and biological antagonists against with plant } \\
\text { pathogens and can increase plant resistance through primed seeds. This study } \\
\text { aimed to determine the activity of Pseudomonas spp. and Bacillus sp. in } \\
\text { promoting germination and seedling growth of tomato plants. The native isolates } \\
\text { the strain Pf1 recorded the increased vigour index of tomato seedlings }\end{array}$ \\
\hline Article Info & $\begin{array}{l}\text { significantly. It recorded } 100 \text { percent germination, increased mean shoot and root } \\
\text { length of } 8.26 \text { and } 14.33 \mathrm{~cm} \text { respectively with vigour index of } 2259 \text {. This was }\end{array}$ \\
\hline $\begin{array}{l}\text { Accepted: } \\
\text { 24 September } 2017 \\
\text { Available Online: } \\
\text { 10 November } 2017\end{array}$ & $\begin{array}{l}\text { followed by EPCO16 with } 98.64 \text { percent germination, increased mean shoot and } \\
\text { root length of } 7.82 \text { and } 13.44 \mathrm{~cm} \text { respectively with vigour index of } 2097 \text {, followed } \\
\text { by EPC } 5 \text { with } 97.32 \text { percent germination, increased mean shoot and root length of } \\
7.63 \text { and } 13.14 \mathrm{~cm} \text { respectively with vigour index of } 2021 \text {. }\end{array}$ \\
\hline
\end{tabular}

\section{Introduction}

Rhizobacteria is organizational group of bacteria presented around root surface which promoting the plant growth and increase the soil fertility by uptake the minerals of root exudates from plant and directly given immune response against with suppression of the pathogens (Sarma et al., 2009). This rhizobacterial community have produced various progress viz., antibiosis, siderophore synthesis, cellulolysis under soil competent conditions against with virulent pathogens (Van Peer and Schippers, 1988). It's mostly contributed with Pseudomonas. sp and Gram positive Bacillus spp. They are specific nature in production of phytohormones (Cytokinin, IAA and GA), antibiotic peptides, mineral solvents of nitrogen fixers (Tenuta, 2004). Rosenblueth and Martinez-Romero (2006) reported Pseudomonas spp. has a positive effect by occupying root colonization without morphological changes in plant. Seeds coated with Fluorescent Pseudomonads increased the plant growth of rice and cotton by 27 and 40 per cent respectively (Sakthivel et al., 1986). This study was conducted to obtain information about tomato seedlings 
germination and root anatomy through different treatments of PGPR.

\section{Materials and Methods}

\section{Collection and isolation rhizobacteria}

The PGPR isolates viz., Pseudomonas fluorescens isolate (Pf1), Bacillus subtilis isolates (EPCO16, EPC5 and EPC8) and T. viride (Tv1) isolates were obtained from the Culture collection section, Department of Plant Pathology, TNAU, Coimbatore for this study. Some rhizobacterial isolates were isolated from different places during the respective crop. Pure cultures of Pseudomonas fluorescens and Bacillus subtilis isolates were maintained on $\mathrm{KB}$ and NA slants respectively at $4^{\circ} \mathrm{C}$ for further studies.

\section{Seed source}

The seeds of tomato $c v$. PKM 1 were obtained from the Department of Vegetable Crops, Horticultural College and Research Institute, Periyakulam, Theni, Tamil Nadu.

\section{Seed bacterization}

Seeds of tomato ( $c v$. PKM1) were surface sterilized with two percent sodium hypochlorite for $30 \mathrm{sec}$. rinsed in sterile distilled water and dried overnight. Ten $\mathrm{ml}$ of antagonist inoculum containing $3 \times 10^{8} \mathrm{cfu}$ $\mathrm{ml}^{-1}$ was taken in a Petri dish. To this, $100 \mathrm{mg}$ of Carboxy Methyl Cellulose (CMC) was added as an adhesive material. One gram of seeds was soaked in $10 \mathrm{ml}$ of rhizobacterial suspension like Pseudomonas spp. and Bacillus spp. (containing $3 \times 10^{8} \mathrm{cfu} \mathrm{m}^{-1}$ ) for 2 $\mathrm{h}$ and air dried overnight in a sterile Petri dish. For fungal antagonists, one gram of seeds was soaked in $10 \mathrm{ml}$ of antagonistic suspension (containing $10^{8}$ spores $/ \mathrm{ml}$ ) for 30 min air dried in sterile Petri dish.
Twenty five seeds were kept over the presoaked germination paper. The seeds were held in position by placing another presoaked germination paper strip and gently pressed. The polythene sheet along with seeds were then rolled and incubated in growth chamber for 10 days. Three replications were maintained for each treatment (ISTA, 1999). The root length and shoot length of individual seedlings were measured and the germination per cent of seeds was also calculated. The seedling vigour index was calculated by using the formula as described by Abdul Baki and Anderson (1973).

Vigour Index $=($ Mean root length + Mean shoot length) x Germination (\%)

\section{Results and Discussion}

The tomato seeds were treated with suspensions of different rhizobacteria under in vitro conditions and observed for their growth promotion by roll towel method. The result revealed that in general all the treatments induced the plant growth promotion significantly over untreated check. Among the rhizobacteria, the strain Pf1 recorded the increased vigour index of tomato seedlings significantly.

It recorded 100 percent germination, increased mean shoot and root length of 8.26 and $14.33 \mathrm{~cm}$ respectively with vigour index of 2259. This was followed by EPCO16 with 98.64 percent germination, increased mean shoot and root length of 7.82 and $13.44 \mathrm{~cm}$ respectively with vigour index of 2097, followed by EPC 5 with 97.32 percent germination, increased mean shoot and root length of 7.63 and $13.14 \mathrm{~cm}$ respectively with vigour index of 2021. The control recorded the lowest germination of 66.64 percent, least mean shoot and root length of 6.52 and 9.73 $\mathrm{cm}$ respectively with vigour index of 1082 (Table 1; Figure 1 and Plate 1). 
Fig.1 Growth promoting activity of PGPR isolates on tomato seedlings in vitro

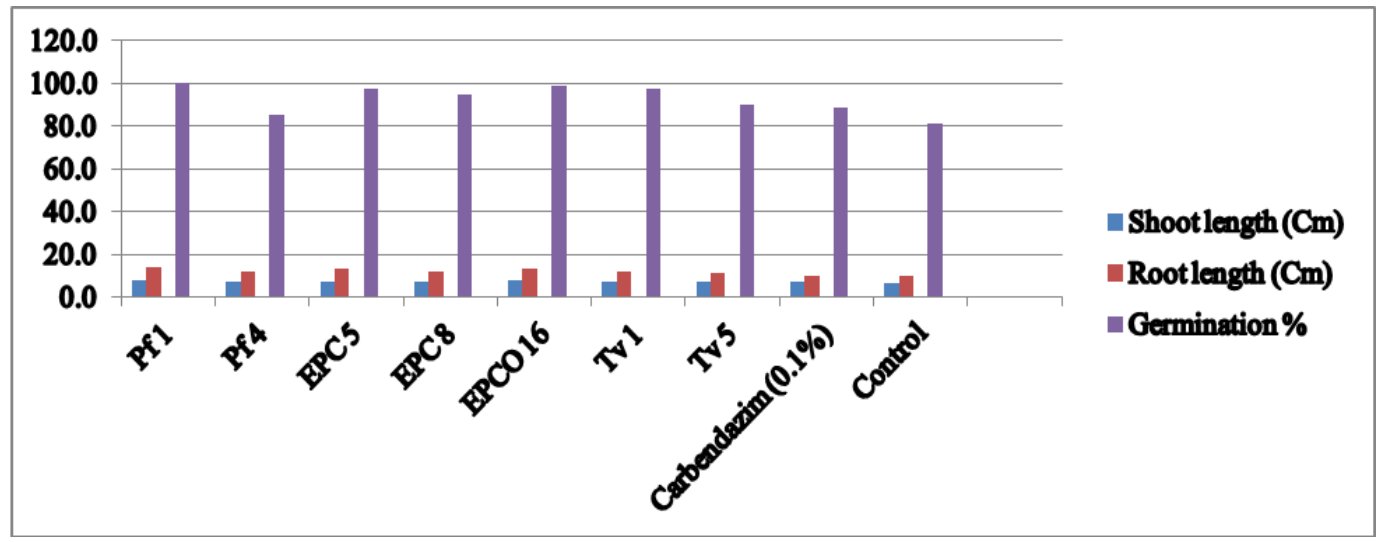

Plate.1 Plant growth promotion of different rhizobacterial isolates on tomato under in vitro

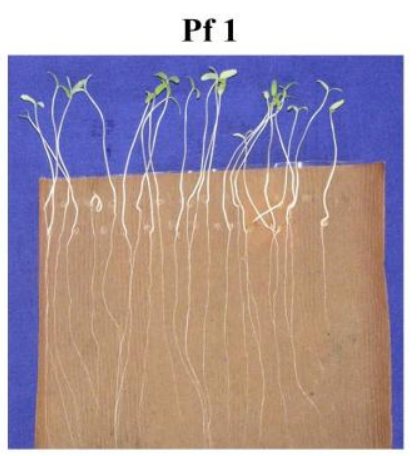

EPC 8

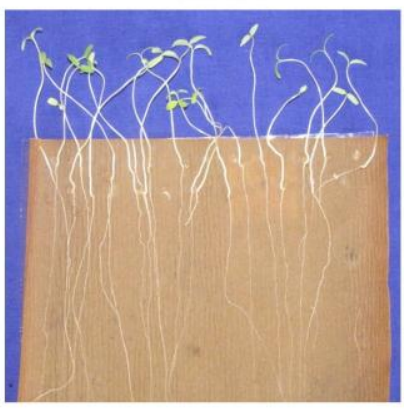

Tv 5

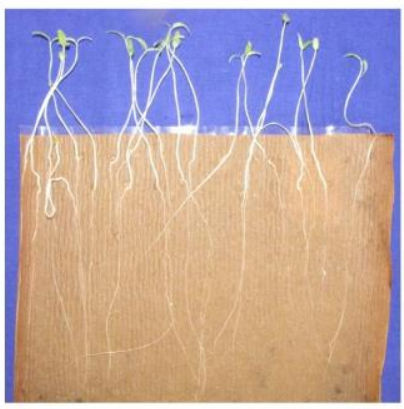

$\operatorname{Pf} 4$

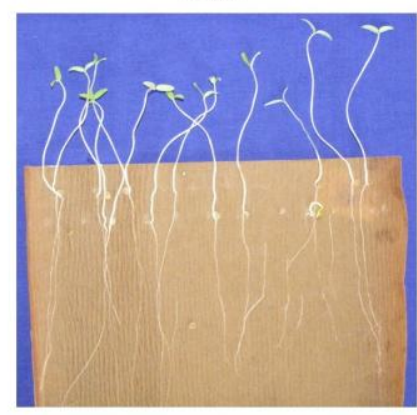

EPCO16

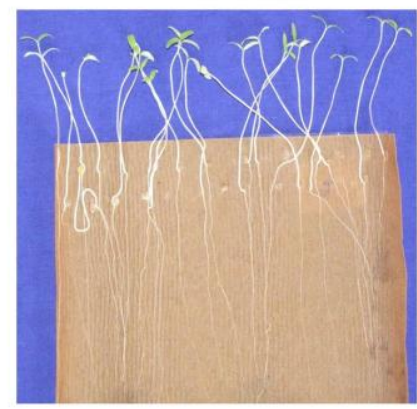

Carbendazim

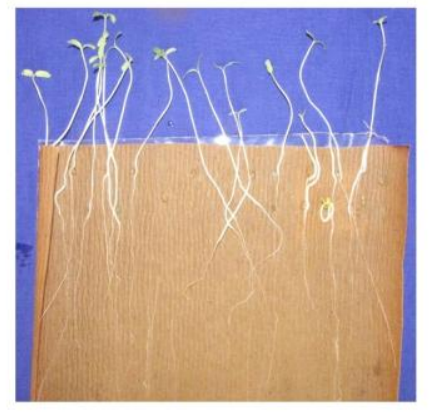

EPC 5

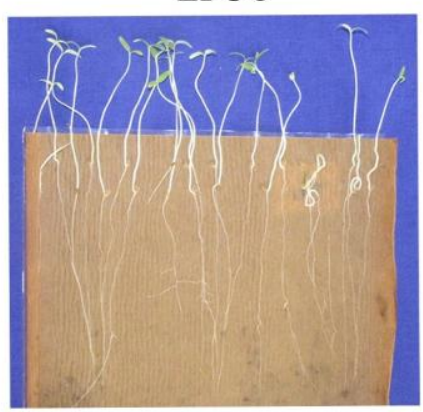

Tv 1

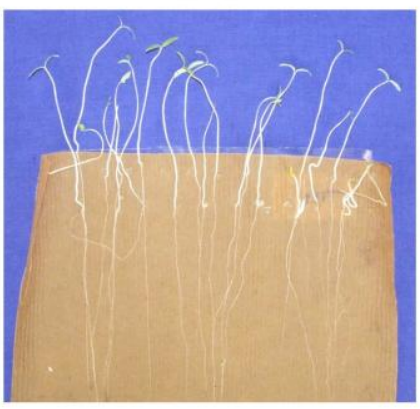

Control

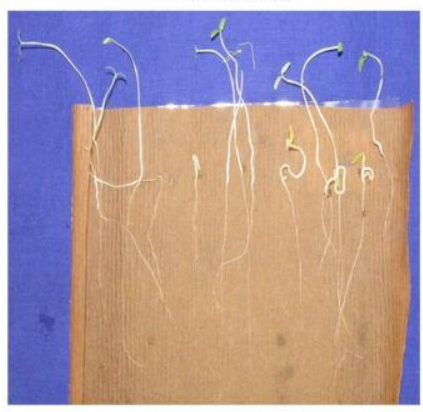


Table.1 Growth promoting activity of PGPR isolates on tomato seedlings in vitro

\begin{tabular}{|c|c|c|c|c|c|}
\hline S.No & Isolate & $\begin{array}{c}\text { Shoot } \\
\text { length }(\mathbf{c m}) *\end{array}$ & $\begin{array}{c}\text { Root } \\
\text { length }(\mathbf{c m})^{*}\end{array}$ & $\begin{array}{c}\text { Germination } \\
(\boldsymbol{\%})\end{array}$ & $\begin{array}{c}\text { Vigour } \\
\text { index }^{*}\end{array}$ \\
\hline 1. & Pf 1 & 8.26 & 14.33 & 100 & $2259.00^{\mathbf{a}}$ \\
\hline 2. & Pf 4 & 7.28 & 12.27 & 85.33 & $1668.20^{\text {bcd }}$ \\
\hline 3. & EPC 5 & 7.63 & 13.14 & 97.32 & $2021.33^{\text {bc }}$ \\
\hline 4. & EPC 8 & 7.61 & 12.33 & 94.64 & $1887.12^{\text {cd }}$ \\
\hline 5. & EPCO16 & 7.82 & 13.44 & 98.64 & $2097.08^{\text {ab }}$ \\
\hline 6. & Tv1 & 7.14 & 11.72 & 97.32 & $1835.45^{\text {de }}$ \\
\hline 7. & Tv5 & 7.11 & 11.22 & 90.00 & $1649.70^{\mathbf{e}}$ \\
\hline 8. & Carbendazim 0.1\% & 7.03 & 10.28 & 88.88 & $1538.51^{\mathbf{f}}$ \\
\hline 9. & Control & 6.52 & 9.73 & 81.00 & $1316.25^{\mathbf{f}}$ \\
\hline
\end{tabular}

* Mean of three replications.

Means in a column followed by same superscript letters are not significantly different according to DMRT.

Efficacy of PGPR strains on plant growth promotion in vitro in roll towel method

In the present study, the seed bacterization with different isolates of rhizobacterial antagonist's viz., Pf 1, Pf 4, EPC 5, EPC 8 and EPCO16, were found to increase the vigour index of the tomato seedlings in vitro. Among the rhizobacterial isolates Pf1 recorded the maximum vigour index of 2259 with 100 percent germination, which was followed by EPCO16 with 98 percent of germination respectively. The results revealed that Pf 1 increased the growth of tomato seedlings significantly when compared to untreated control.

Several reports have indicated that seed bacterization by Pseudomonas and Bacillus spp. was inducing plant growth promotion (Dileep Kumar and Dube, 1992; Brown, 1972). PGPR increased plant growth directly by mediating the production of secondary metabolites and phytohormones such as auxins, cytokinins or gibberellic acid (Kloepper et al., 1993; Beyeler et al., 1999). Rajendran (2006) reported that bacterial strains viz., EPC 5, EPC 8, EPC 15, EPC 29 and EPC 52 were reported to increase the vigour index of rice seedlings significantly.
Nagendran (2011) reported that seed bacterization with bacterial endophytic Bacillus strains viz., EPB 18, EPB 11, EPCO 74, EPB 6 and FZB24 were found to increase the vigour index of the rice seedlings in vitro.

Amaresan et al., (2011) isolated three endophytic bacterial isolates of Bacillus namely BECS3, BECS6 and BECS7 were proved to be very efficient strains as they possess antagonistic as well plant growth promoting activities and showed increase in the plant growth of tomato and chilli by seed bacterization.

\section{Acknowledgement}

Department of Plant pathology, TNAU, Coimbatore.

\section{References}

Abdul Baki, A. A. and Anderson, J. D. 1973. Vigour determination in soybean seed by multiple criteria. Crop Sci., 13: 630633.

Amaresan, N., Jayakumar, V., Krishna, K. and Thajuddin, N. 2011. Endophytic bacteria from tomato and chilli, their diversity and antagonistic potential 
against Ralstonia solanacearum, Archives of Phytopathol. Plant Prot., Available (online): http:// dx.doi.org/ 10.1080/03235408.2011.587273.

Beyeler, M., Keel, C., Michaux, P. and Hass, D. 1999. Enhanced production of indole-3-acetic acid by a genetically modified strain of Pseudomonas fluorescens CHAO affects root growth of cucumber, but does not improve protection of the plant against Pythium root rot. FEMS Microbiol. Ecol., 28: 225-233.

Brown, M.E. 1972. Plant growth substances produced by microorganisms of soil and rhizosphere. J. Appl. Bacteriol., 35: 443-451.

Dileep Kumar, B. S. and Dube, H. C. 1992. Seed bacteriazation with fluorescent Pseudomonads for enhanced plant growth, yield and disease control. Soil Biol. Biochem., 24: 539-542.

ISTA, 1999. International Rules for Seed Testing. Seed Science and Technol., 27: 31.

Kloepper, J. W., Tuzun, S., Liu, L. and Wei, G. 1993. Plant growth-promoting rhizobacteria as inducers of systemic disease resistance. In: Pest Management: Biologically Based Technologies. R. D. Lumsden and J. L.
Waughn (Eds.). American Chemical Society Books, Washington D.C, USA. pp. 156-165

Nagendran, K. 2011. Exploitation of endophytes for the management of major diseases of rice. M.Sc. (Ag.) Thesis, Tamil Nadu Agricultural University, Coimbatore, India. pp. 200.

Rajendran, L. 2006. Biotechnological tools and methods for early detection and sustainable management of basal stem rot disease in coconut plantation using microbial consortia. Ph.D. (Ag.) Thesis, Tamil Nadu Agricultural University, Coimbatore, India. p. 201.

Rosenblueth, M., Martinez-Romero, E., 2006. Bacterial endophytes and their interactions with hosts. Mol PlantMicrobe Interact, 19: 827-837.

Sakthivel, N., Sivamani, E., Unnamalai, N. and Gnamanickam, S.S.1986. Plant growth promoting rhizobacteria in enhancing plant growth and suppressing plant pathogens. Curr. Sci., 55: 22-25.

Sarma, M. V., Saharan, R. K., Prakash, K., Bisaria, A., Sahai, V., 2009. Application of fluorescent Pseudomonads inoculant formulations on Vigna mungo through field trial. Int J. Biol. Life Sci., 1(1): 2529.3.

\section{How to cite this article:}

Murali Sankar, P., T. Raguchander and Shanmugabackiam, S. 2017. Seed Bacterization a Novel Prime Tool for Growth Promotion in Tomato (Solanum lycopersicum M.) under in vitro. Int.J.Curr.Microbiol.App.Sci. 6(11): 3076-3080. doi: https://doi.org/10.20546/ijcmas.2017.611.360 